JOURNAL OF NURSING PRACTICE AND EDUCATION

VOL. 01 NO. 02, JUNI 2021

DOI: $10.34305 / \mathrm{JNPE} . \mathrm{V} 1 \mathrm{I} 2.293$
Ciptaan disebarluaskan di bawah

Lisensi Creative

CommonsAtribusi-NonKomersialBerbagiSerupa 4.0

\title{
HUBUNGAN ANTARA KARAKTERISTIK PASANGAN USIA SUBUR DENGAN PEMILIHAN ALAT KONTRASEPSI IUD DI PUSKESMAS LOSARI KECAMATAN LOSARI KABUPATEN BREBES TAHUN 2018
}

\author{
Intan Monik Pratami \\ STIKes Brebes \\ intanmonikpratami@gmail.com
}

\begin{abstract}
Abstrak
Perkembangan penduduk dunia saat ini terus mengalami peningkatan, Indonesia merupakan salah satu dengan jumlah penduduk terbanyak ke 4 di dunia. Perkembangan penduduk di Indonesia setiap tahun meningkat dikarenakan banyaknya pasangan usia subur yang menikah di usia muda karena rendahnya pendidikan yang didapat. Dalam hal ini pemerintah melalui BKKBN untuk meningkatkan pelayanan $\mathrm{KB}$ diharapkan hal ini dapat mencegah ledakan jumlah penduduk dengan cara Keluarga Berencana (KB). Ada berbagai jenis kontrasepsi, salah satunya kontrasepsi jangka panjang. Efektifitasnya yang tinggi dapat diandalkan sebagai metode kontrasepsi namun jumlah akseptornya sangat tinggi dibandingkan metode lain. Terdapat berbagai faktor yang mempengaruhi antara lain tingkat pengetahuan PUS.Tujuan penelitian ini adalah menentukan hubungan karakteristik ibu dengan pemilihan kontrasepsi. Jenis penelitian yang digunakan bersifat deskriptif analitik dengan metode cross sectional. Populasi penelitian adalah seluruh pasangan usia subur yang sudah menikah dan masih aktif menjadi akseptor KB. Sampel diambil dengan menggunakan teknik consecutive sampling berjumlah 60 responden. Variabel dependen pada penelitian ini adalah umur ibu, Pekerjaandan tingkat pendidikan sedangkan variabel independen adalah pemilihan kontrasepsi. Berdasarkan Hasil Penelitian 60 responden memilih kontrasepsi Suntik (38,34\%) dan 67 responden memilih kontrasepsi non-IUD $(61,66 \%)$. Hasil analisis bivariat menunjukkan tingkat pendidikan memiliki hubungan yang bermakna dengan pemilihan kontrasepsi $(p=0,000)$. Dapat disimpulkan bahwa ada hubungan bermakna antara tingkat pendidikan dengan pemilihan kontrasepsi. Seseorang dengan tingkat pendidikan tinggi cenderung memilih kontrasepsi IUD.
\end{abstract}

Kata Kunci : Pemilihan, Metode, IUD 
JOURNAL OF NURSING PRACTICE AND EDUCATION VOL. 01 No. 02, JUNI 2021

DOI: $\underline{10.34305 / \mathrm{JNPE} . \mathrm{V} 1 \mathrm{I} 2.293}$

Indonesia merupakan negara berkembang dengan berbagai permasalahan kependudukan yang masih perlu ditangani. Menurut data Badan Pusat Statistik proyeksi jumlah penduduk Indonesia tahun 2015 mencapai 258,4 juta jiwa dengan laju pertumbuhan 1,3\% pertahun (BPS, 2015). Dalam mengatasi permasalahan kependudukan bangsa Indonesia mengadakan program Keluarga Berencana (KB). Untuk mencapai tujuan tersebut, pengelolaan program nasional KB diarahkan pada bentuk sasaran yaitu sasaran langsung berupa pasangan usia subur (PUS), pasangan usia subur 20 - 35 tahun dan sasaran tidak langsung melalui organisasi, lembaga kemasyarakatan, instansi pemerintah maupun swasta, tokoh masyarakat. Program KB bertujuan mewujudkan keluarga kecil yang bahagia dan sejahtera (Hartanto, 2009).

Keluarga berencana merupakan suatu upaya mengatur kelahiran anak, jarak dan usia ideal melahirkan untuk mewujudkan keluarga yang berkualitas. Keluarga berencana memiliki peranan dalam menurunkan resiko kematian ibu melalui pencegahan kehamilan, menunda kehamilan atau membatasi kehamilan. Pelayanan keluarga berencana merupakan upaya pelayanan kesehatan preventif yang dasar dan utama (BKKBN, 2011).
Ciptaan disebarluaskan di bawah

Lisensi Creative

CommonsAtribusi-NonKomersialBerbagiSerupa 4.0

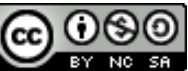

Kontrasepsi adalah suatu usaha untuk mencegah untuk terjadinya kehamilan, usaha-usaha itu dapat bersifat sementara dapat juga bersifat permanen. Berbagai macam metode kontasepsi ditawarkan mulai dari metode sederhana seperti metode kalender, kondom, dan metode modern seperti pil, suntik, implant, Intra Uterine Device (IUD), hingga kontrasepsi mantap yaitu Medis Operatif Wanita (MOP) dan Medis Operatif Pria (MOP) (BKKBN, 2009). Saat ini terdapat metode-metode kontrasepsi dengan efektivitas bervariasi. Banyak wanita mengalami kesulitan dalam menentukan pilihan jenis kontrasepsi. Berbagai faktor harus dipertimbangkan, antara lain usia, paritas, pasangan, usia anak terkecil, biaya, budaya dan tingkat pendidikan (Saifuddin $A B, 2006)$.

Pada tahun 2011, BKKBN mempriotitaskan penggunaan IUD (Intrauterine Device) sebagai strategi dalam meningkatkan Metode Kontrasepsi Jangka Panjang (MKJP). IUD dianggap efektif karena merupakan kontrasepsi jangka panjang yang ideal dalam menjarangkan kehamilan (Puspitasari D, 2011).

Berdasarkan Teori Green dan Kreuter, bahwa pemakaian alat kontrasepsi dipengaruhi oleh beberapa faktor yakni 
JOURNAL OF NURSING PRACTICE AND EDUCATION VOL. 01 NO. 02, JUNI 2021

DOI: $\underline{10.34305 / \mathrm{JNPE} . \mathrm{V} 1 \mathrm{I} 2.293}$

umur, pendidikan, pengetahuan, jumlah anak hidup, ketersediaan alat kontrasepsi, dukungan petugas kesehatan, kesepakatan suami dan istri dan efek samping. KB suntik adalah kontrasepsi yang paling diminati di wilayah kerja Puskesmas Larangan, hal ini dikarenakan banyak wanita usia subur yang merasa cocok dalam hal Beberapa faktor yang mempengaruhi penggunaan kontrasepsi antara lain pengetahuan, informasi oleh petugas lapangan $\mathrm{KB}$ dan dukungan suami. Pengetahuan memiliki hubungan yang signifikan dengan pengetahuan alat kontrasepsi, semakin baik pengetahuan seseorang semakin rasional dalam menggunakan alat kontrasepsi. Selain itu tingginya tingkat pendidikan seseorang juga akan mendukung mempercepat penerimaan informasi $\mathrm{KB}$ pada pasangan usia subur. Seorang wanita mengalami kesulitan didalam menentukan jenis kontrasepsi. Hal ini tidak hanya karena terbatasnya metode yang tersedia tetapi ketidak tahuan PUS tentang persyaratan dan keamanan metode kontrasepsi. Pengetahuan tentang perlunya keluarga berencana serta pengetahuan tentang alat kontrasepsi yang digunakan berpengaruh pada penggunaan alat kontrasepsi. Seseorang akan tertarik pada suatu obyek apabila orang tersebut mengetahui obyek tersebut, demikian pula
Ciptaan disebarluaskan di bawah Lisensi Creative CommonsAtribusi-NonKomersialBerbagiSerupa 4.0

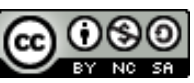

dengan alat kontrasepsi memiliki karakteristik khusus, seperti bentuknya, cara memasang, keuntungan, kerugian, waktu kontrol dan waktu pemasangan, serta efek samping.Informasi yang baik dari petugas membantu klien dalam memilih dan menentukan jenis kontrasepsi yang dipakai. Informasi yang baik akan memberikan kepuasan klien yang berdampak pada penggunaan kontrasepsi yang lebih lama sehingga membantu keberhasilan KB. Selain itu, dukungan suami juga mempengaruhi penggunaan penggunaan kontrasepsi. Klien yang diberikan dukungan oleh suami akan menggunakan kontrasepsi secara terus menerus sedangkan yang tidak mendapat dukungan suami akan sedikit menggunakan kontrasepsi.

Menurut data yang diperoleh dari Petugas Lapangan Keluarga Berencana (PLKB) tahun 2017 di Puskesmas Losari Kabupaten Brebes tercatat jumlah peserta KB aktif sebanyak 403 dengan perincian, IUD (2,977\%), MOP (0\%), kondom $(0,248 \%)$, implant $(2,233 \%)$, suntikan $(61,786 \%)$, dan pil $(31,761 \%)$.

Berdasarkan data PLKB Puskesmas Losaric (2017) di Puskesmas Losari bahwa minat peserta $\mathrm{KB}$ untuk memilih metode suntik lebih tinggi dari pada metode kontrasepsi lainnya, Melihat hal tersebut 
JOURNAL OF NURSING PRACTICE AND EDUCATION

VOL. 01 No. 02, JUNI 2021

DOI: $\underline{10.34305 / \mathrm{JNPE} . \mathrm{V} 1 \mathrm{I} 2.293}$

peneliti tertarik untuk mengetahui gambaran pengetahuan dan dukungan suami dalam pemilihan metode kontrasepsi Iud di Puskesmas Losari Kabupaten Brebes.

\section{Metode}

Peneliti menggunakan metode cross sectional yang dilakukan di Puskesmas Losari Kabupaten Brebes dari Februari Maret 2018.

Kriteria sampel pada penelitian ini adalah semua seluruh Pasangan Usia Subur (PUS) yang sudah menikah dan masih aktif menjadi akseptor KB yang didapatkan sampel sebanyak 60 responden. Penelitian
Ciptaan disebarluaskan di bawah

Lisensi Creative

Commons Atribusi-NonKomersialBerbagiSerupa 4.0

ini dilakukan dengan membagikan kuesioner. Metode pemilihan sampel adalah consecutive sampling. Langkah-langkah pengolahan data adalah dengan melakukan pemeriksaan data (editing), pemberian kode pada setiap data (coding), memasukkan data (entry), dan pemeriksaan kembali terhadap kemungkinan kesalahan (cleaning). Data yang diperoleh dianalisis secara univariat dan bivariat.

\section{Hasil dan Pembahasan}

Penelitian ini dilakukan pada 60 responden yaitu ibu akseptor KB IUD di Puskesmas Losari Kabupaten Brebes

TABEL 1 Karakteristik Akseptor

\begin{tabular}{ccc}
\hline Karakteristik & Frekuensi & $\%$ \\
\hline Umur & & \\
$<20$ tahun & - & 0 \\
$21-35$ Tahun & 23 & 38,33 \\
$>35$ tahun & 37 & 61,67 \\
\hline Jumlah & 60 & 100 \\
\hline
\end{tabular}

Berdasarkan umur menunjukkan 60 responden kelompok umur terbanyak adalah golongan umur > 35 tahun $(61,67 \%)$ dibanding kelompok 21 - 35 tahun 23 responden $(38,33 \%)$,

Menurut Mubarak (2007) bahwa dengan bertambahnya umur sesorang akan terjadi perubahan pada aspek fisik dan psikologi (mental). Pada usia ini merupakan usia yang masih produktif, semakin meningkatnya umur maka prestasi berpengetahuan semakin baik, jadi semakin cukup umur maka tingkat.

Umur merupakan hal yang sangat berperan dalam penentuan untuk menggunakan alat kontrasepsi karena pada 
JOURNAL OF NURSING PRACTICE AND EDUCATION VOL. 01 NO. 02, JUNI 2021

DOI: $\underline{10.34305 / \mathrm{JNPE} . \mathrm{V} 1 \mathrm{I} 2.293}$

fase-fase tertentu dari umur menentukan tingkat reproduksi seseorang.

Menurut Notoatmodjo (2007) pada usia madya, individu akan lebih berperan aktif dalam masyarakat dan kehidupan sosial serta lebih banyak melakukan persiapan demi suksesnya upaya menyesuaikan diri menuju usia tua, selain itu orang usia madya akan lebih banyak menggunakan banyak waktu untuk membaca. Kemampuan intelektual, pemecahan masalah, dan kemampuan verbal dilaporkan hampir tidak ada penurunan pada usia ini.

Semakin matang usia seseorang akan semakin banyak pengalaman hidup yang dimiliki dan mudah untuk menerima perubahan perilaku, karena merupakan usia produktif dan paling ideal. Bila ditinjau pola dasar penggunaan kontrasepsi yang rasional maka masa mencegah kehamilan $(<20$ tahun) dianjurkan untuk menggunakan
Ciptaan disebarluaskan di bawah Lisensi Creative

CommonsAtribusi-NonKomersialBerbagiSerupa 4.0

kontrasepsi dengan urutan yang disarankan pil KB,AKDR/IUD, dan kondom sedangkan pada masa menjarangkan kehamilan (20-30 tahun) dianjurkan untuk menggunakan kontrasepsi dengan urutan AKDR/IUD, pil $\mathrm{KB}$, suntikan, implant/susuk, kondom dan kontap (Notoatmodjo, 2015).

Penelitian ini sejalan dengan Fitri (2012) menyatakan bahwa tidak ada hubungan yang bermakna antara umur dengan pemilihan kontrasepsi. Hasil ini bertentangan dengan Arifuddin (2013) yang menyatakan ada hubungan yang bermakna antara umur dengan pemilihan kontrasepsi.

Pada masa mengakhiri kehamilan (>30 tahun) dianjurkan untuk menggunakan kontrasepsi dengan urutan kontap, AKDR/ IUD, implant, suntik, pil KB, dan kondom. Dengan demikian umur akan menentukan dalam pemilihanjenis kontrasepsi yang digunakan.

TABEL 2 Pendidikan Responden

\begin{tabular}{ccc}
\hline Karakteristik & Frekuensi & $\%$ \\
\hline Tingkat Pendidikan & & \\
Rendah & 5 & 8,33 \\
Sedang & 32 & 53,33 \\
Tinggi & 23 & 38,34 \\
\hline Jumlah & 60 & 100 \\
\hline
\end{tabular}

Berdasarkan hasil penelitian 60 responden $(8,33 \%)$ ibu memiliki tingkat pendidikan rendah, 32 responden ( 53,33\%) memiliki tingkat pendidikan sedang, dan 23 responden (38,34\% ) ibu memiliki tingkat pendidikan tinggi. Semakin tinggi tingkat 
JOURNAL OF NURSING PRACTICE AND EDUCATION

VOL. 01 No. 02, JUNI 2021

DOI: $\underline{10.34305 / \mathrm{JNPE} . \mathrm{V} 1 \mathrm{I} 2.293}$

pendidikan akan jelas mempengaruhi pribadi seseorang dalam berpendapat, berpikir, bersikap, lebih mandiri dan rasional dalam mengambil keputusan dan tindakan.

Menurut Notoatmodjo pengetahuan adalah hasil tahu dan ini terjadi setelah orang melakukan tindakan terhadap suatu obyek tertentu. Penginderaan terjadi melalui indera manusia yaitu indera manusia yaitu indera penglihatan, pendengaran, rasa dan raba. Sebagian besar pengetahuan manusia diperoleh melalui mata dan telinga.

Hal ini juga akan mempengaruhi secara langsung seseorang dalam hal
Ciptaan disebarluaskan di bawah

$\underline{\text { Lisensi Creative }}$

Commons Atribusi-NonKomersialBerbagiSerupa 4.0

pengetahuannya akan orientasi hidupnya termasuk dalam merencanakan keluarganya. Pendidikan juga akan meningkatkan kesadaran wanita terhadap manfaat yang dapat dinikmati bila ia mempunyai jumlah anak sedikit. Tinggi rendahnya tingkat sosial ekonomi yang dimiliki oleh responden, membuat responden sangat susah untuk membiayai atau melanjutkan pendidikannya, disatu sisi pemenuhan kebutuhan sehari-hari sangat penting untuk dipenuhi.

TABEL 3 Pemilihan Kontrasepsi

\begin{tabular}{lcc}
\hline \multicolumn{1}{c}{ Karakteristik } & Frekuensi & $\%$ \\
\hline Pemilihan Kontrasepsi & & \\
IUD & 21 & 35 \\
Non IUD & 39 & 65 \\
\hline Jumlah & 60 & 100 \\
\hline
\end{tabular}

Berdasarkan hasil penelitian 21 dan 39 responden (65\%) ibu yang tidak responden (35\%) ibu yang memilih IUD, memilih IUD.

TABEL 4 Hubungan Umur dan Pemilihan kontrasepsi

\begin{tabular}{cccccc}
\hline \multirow{2}{*}{ Umur } & \multicolumn{4}{c}{ Pemilihan Kontrasepsi } & \multirow{2}{*}{$\mathrm{p}$} \\
\cline { 2 - 4 } & \multicolumn{2}{c}{ IUD } & \multicolumn{2}{c}{ Non IUD } & \\
\cline { 2 - 5 } & $\mathrm{f}$ & $\%$ & $\mathrm{f}$ & $\%$ & \\
\hline 20-35 thun & 11 & 40,74 & 16 & 59,26 & \multirow{2}{*}{0,590} \\
$>35$ th & 10 & 30,30 & 23 & 69,70 & \\
\hline Jumlah & 21 & 35 & 39 & 65 & \\
\hline
\end{tabular}

Berdasarkan Tabel diatas, dapat dilihat bahwa 44 responden yang memiliki umur diantara 20-35 tahun, 11 responden (40,74\%) memilih kontrasepsi IUD dan 16 
JOURNAL OF NURSING PRACTICE AND EDUCATION VOL. 01 No. 02, JUNI 2021

DOI: $\underline{10.34305 / \mathrm{JNPE} . \mathrm{V} 1 \mathrm{I} 2.293}$

responden $(59,26 \%)$ memilih kontrasepsi non IUD. Sedangkan 33 responden yang memiliki umur diatas 35 tahun, 10 reseponden $(30,30 \%)$ memilih kontrasepsi IUD dan 23 responden $(69,70 \%)$ memilih non IUD.

\section{Ciptaan disebarluaskan di bawah \\ Lisensi Creative \\ Commons Atribusi-NonKomersial- BerbagiSerupa 4.0}

Hasil uji statistik didapatkan $\mathrm{p}=$ 0,590 ( $>0,05)$. Berdasarkan hasil tersebut, dapat disimpulkan bahwa tidak ada hubungan yang bermakna antara umur dengan pemilihan kontrasepsi.

TABEL 5 Hubungan Tingkat Pendidikan dan Pemilihan kontrasepsi

\begin{tabular}{cccccc}
\hline \multirow{2}{*}{$\begin{array}{c}\text { Tingkat } \\
\text { Pendidikan }\end{array}$} & \multicolumn{4}{c}{ Pemilihan Kontrasepsi } & \multirow{2}{*}{$\mathrm{p}$} \\
\cline { 2 - 4 } & \multicolumn{2}{c}{ IUD } & \multicolumn{2}{c}{ Non IUD } & \\
\cline { 2 - 4 } & $\mathrm{f}$ & $\%$ & $\mathrm{f}$ & $\%$ & \\
\hline Rendah & 4 & 44,44 & 5 & 55,56 & \\
Sedang & 7 & 21,88 & 25 & 78,12 & 0,000 \\
Tinggi & 10 & 52,63 & 9 & 47,37 & \\
\hline Jumlah & 21 & 35 & 39 & 65 &
\end{tabular}

Berdasarkan Tabel, dapat dilihat bahwa 9 responden yang memiliki tingkat pendidikan rendah, 4 responden $(44,4 \%)$ memilih kontrasepsi IUD dan 5 responden $(55,56 \%)$ memilih kontrasepsi non IUD. Dari 32 responden yang memiliki tingkat pendidikan sedang, 7 responden $(21,8 \%)$ memilih kontrasepsi IUD dan 25 responden $(78,12 \%)$ memilih kontrasepsi non IUD. Sisanya dari 19 responden yang memiliki tingkat pendidikan tinggi, 10 responden $(52,63 \%)$ memilih kontrasepsi IUD dan 9 responden $(47,37 \%)$ memilih kontrasepsi non IUD.

Hasil uji statistik didapatkan $\mathrm{p}=$ 0,000 ( $\mathrm{p}<0,05)$. Berdasarkan hasil tersebut dapat disimpulkan bahwa ada hubungan yang bermakna antara tingkat pendidikan dengan pemilihan kontrasepsi.

Penelitian ini sejalan dengan Bernadus \& Madianung (2013) menyatakan bahwa terdapat hubungan antara tingkat pendidikan dengan pemilihan AKDR. penelitian ini bertentangan dengan Utami (2013) yang mengatakan tidak ada hubungan yang bermakna antara tingkat pendidikan dengan pemilihan kontrasepsi. Pendidikan merupakan salah satu faktor yang mempengaruhi seseorang dalam menerima ide baru, termasuk menggunakan kontrasepsi. Seseorang yang memiliki tingkat pendidikan tinggi akan lebih luas dan mudah dalam menerima ide, lebih mandiri 
JOURNAL OF NURSING PRACTICE AND EDUCATION

VOL. 01 NO. 02, JUNI 2021

DOI: $\underline{10.34305 / J N P E . V 1 I 2.293}$

dan rasional dalam mengambil suatu keputusan dan tindakan.

\section{Kesimpulan}

1. Tidak ada hubungan yang bermakna antara umur dengan pemilihan kontrasepsi.

2. Ada hubungan yang bermakna antara tingkat pendidikan dengan pemilihan kontrasepsi

\section{Saran}

Berdasarkan kesimpulan diatas, maka saran yang dapat diberikan adalah Puskesmas Losari dapat meningkatkan peran petugas lapangan keluarga berencana ( PLKB ) dan Kader dalam memberikan penyuluhan terkait penggunaan alat kontrasepsi. Perlunya penelitian lebih lanjut dilihat dari sisi petugas lapangan dan Kader terhadap kesesuaian penggunaan KB .

\section{Daftar Pustaka}

Arifuddin M. (2013). Faktor Yang Berhubungan dengan Pemilihan Kontrasepsi Hormonal Pasutri di Wilayah Kerja Puskesmas Lampa Kecamatan Duampanua Kabupaten Pinrang. Jurnal Hasanuddin University, 5(7).

Bernadus JD, \& Madianung A. (2013). Faktor - Faktor Yang Berhubungan dengan Pemilihan Alat Kontrasepsi dalam Rahim (AKDR) bagi Akseptor KB di Puskesmas Jailolo. Jurnal E-
Ciptaan disebarluaskan di bawah Lisensi Creative

CommonsAtribusi-NonKomersialBerbagiSerupa 4.0

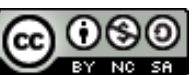

NERS (Ens).

BKKBN. (2009). Laporan Hasil Pelayanan Kontrasepsi.

BKKBN. (2011). Kamus Istilah Kependudukan dan Keluarga Berencana Nasional. Direktorat Teknologi Informasi dan Dokumentasi.

BPS. (2015). Proyeksi Pertumbuhan Penduduk.

Fitri. (2012). Hubungan Faktor Predisposisi, Faktor Pemungkin dan Faktor Penguat dengan Pemilihan Kontrasepsi IUD di Wilayah Kerja Puskesmas Pagaran Tapah Darussalam Kabupaten Rokan Hulu Provinsi RIAU.

Hartanto, H. (2009). Keluarga Berencana dan Kontrasepsi. Pustaka Sinar Harapan.

Mubarak. (2007). Promosi Kesehatan Sebuah Pengamatan Proses Belajar mengajar dalam Pendidikan. Graha Ilmu.

Notoatmodjo, S. (2007). Promosi Kesehatan \& Ilmu Prilaku. Rineka Cipta.

Notoatmodjo, S. (2015). Promosi Kesehatan dan Perilaku kesehatan. Rineka Cipta.

PLKB Puskesmas Losaric. (2017). Laporan Hasil Pelayanan Kontrasepsi.

Puspitasari D. (2011). Kajian Implementasi Kebijakan Pengunaan Kontrasepsi IUD. Pusat Penelitian Dan Pengembangan KB-KS BKKBN.

Saifuddin AB. (2006). Buku Panduan Praktis Pelayanan Kontrasepsi. Bina 
JOURNAL OF NURSING PRACTICE AND EDUCATION VOL. 01 No. 02, JUNI 2021

DOI: $\underline{10.34305 / J N P E . V 1 I 2.293}$

Pustaka Sarwono Prawiroharjo.

Utami, S. (2013). Faktor-Faktor Yang Berhubungan dengan Unmet Need KB
Ciptaan disebarluaskan di bawah Lisensi Creative CommonsAtribusi-NonKomersialBerbagiSerupa 4.0

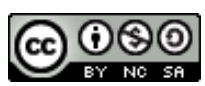

Pasca-Salin IUD Post-Placenta di Kamar Rawat Pasca-Bersalin RSUP. M. Jamil. JKA, 2 (3), 159-161. 